\title{
Characteristics of water sludge from Cracow Water Treatment Plants - case study
}

\author{
Renata Gmurkowska ${ }^{1, *}$ \\ ${ }^{1}$ University of Technology, Department of Environmental Engineering, ul. Warszawska 24, \\ Cracow 31-155, Poland
}

\begin{abstract}
During water treatment a large amount of sludge is created - in the form of sewage and sediments. The largest amounts of sludge are produced during coagulation, ozonation and backwashing rapid filters. The quality and quantity of treated water, the type and dose of used coagulants are factors affecting the quantity, composition and properties of the sludge. Sludge produced during processing of drinking water is important problem and their quantity has been increasing. The study focuses on characteristics of water treatment sludge from four water treatment plants in Cracow. It includes theoretical and experimental part. The first part is based on analysis of literature and information obtained from MPWiK [3]. The second experimental part, concerns the analysis of dry matter, organic dry matter, capillary suction time and visual parameters: the color and consistency of the sludge. Result shows that every sludge contains organic matter. The highest concentrations of organic compounds and the largest diversity has been observed in the sludge collected in the Water Treatment Plant Raba, reaching even up to $70 \%$ of organic compounds in the dry mass of sludge.
\end{abstract}

\section{Introduction}

Water treatment plants, apart from the main product - a potable water, generate also some by-products (waste) such as e.g. hydrated sediments formed during the coagulation, sedimentation and ion exchange processes. The waste include also technological wastewater i.e. water resulting from backwashing of rapid filters, iron and manganese filters or ion exchangers. The amount of waste is closely related to the raw water quality, the assumed process efficiency and the type and doses of reagents [1]. Due to the more stringent quality standards applied to drinking water (the Regulation of the Minister of Health of December 7, 2017 (Journal of Laws, 2017, item 2229) the amount of sludge is constantly increasing, as well. The sludge produced during a water treatment processes (water sludge) can be polluted with heavy metals; treatment a surface water may also generate waste with polycyclic aromatic hydrocarbons (PAH), pesticides, chlorinated hydrocarbons and polyelectrolytes dosed during water treatment. These compounds are considered hazardous and therefore have to be monitored [2]. They can strongly limit a possible sludge reuse and management. The biological composition of water sludge

*Corresponding author : renata.gmurkowska@gmail.com 
depends primarily on quality of a treated water. Sludge resulting from a surface water treatment is definitely more biologically contaminated then sludge resulting from a groundwater treatment; the former contains a large number of bacteria (including Escherichia coli, Salmonella, Pseudomonas aerubinosa, Legionella), viruses and intestinal parasitic cysts. The number of bacteria found in the coagulation sludge (moisture 99\%) is $2300 / 100 \mathrm{~cm}^{3}$ of sludge [2].

All these issues contributed to changes in the legislation, which in turn forced some changes in sludge management. The new techniques of sludge processing and final handling are investigated. Currently, the legislation tries to limit the amount of by-products. According to the Act of December 14, 2012 on waste (Journal of Laws of 2013, No. 0, item 21 , article 22, chapter 5), sludge is considered a hazardous waste and the waste management costs are borne by the original producer or by the holder. It means that the sludge cannot be utilized, as it was before, without any treatment and its characteristics should be closely monitored. In addition, the Regulation of the Minister of Economy of July 16, 2015 on the admission of waste for landfill entered into force on January 1, 2016; it prohibits a storage of waste (including sewage sludge) with a significant energy potential (over $6 \mathrm{MJ} / \mathrm{kg}$ of dry solids). The new law also limits the possibility of storage and agricultural use of waste considered hazardous and non-hazardous, e.g. water sludge and bottom sediments. Due to a growing pollution of the natural environment, including surface waters, a water sludge may contain and most often contains heavy metals and organic and toxic substances harmful to human health and the environment. However, once organic parts are removed from the sludge, the mineral residue can be disposed as a mineral raw material or safely stored. The following parameters should be specified in such case:

- physic-chemical characteristic of sludge,

- hazardous and toxic substances, including heavy metals,

- pollutants leaching and how it is affected by environmental factors and a deposition time.

For this reason, the physic-chemical characteristic of waste becomes an important issue. Often, it is the waste characteristic and leaching of pollutants that are the basic criteria that help to define: class of waste, the method of a final sludge handling, the process design and efficient operation.

\section{Methods}

The material for the study was collected at three Cracow water treatment plants: ZUW Raba, ZUW Rudawa and ZUW Dłubnia; infiltration ponds at the ZUW Bielany were not included into analysis. Grab sludge samples were collected in clean and properly prepared containers in summer, fall and winter. At the ZUWs Raba and Rudawa, the sludge was collected from sludge drying beds, whereas at the ZUW Dłubnia from a sludge well, located ahead of the dewatering press. The samples were analyzed on the same day in the Laboratory of Water and Wastewater Technology, the Faculty of Environmental Engineering, the Cracow University of Technology. Each sample was tested in triplicate. Analysis of dry solids (DS) and dry volatile solids (DVS) were done according to PN-EN12879:2004, while a capillary suction time (CST) was tested according to PN-EN14701-1:2007. In addition, $\mathrm{pH}$, color and consistency of each sludge sample was determined. 


\section{A research area - technological characteristics of the Cracow water treatment plants}

\subsection{ZUW Raba}

The largest treatment plant in Cracow takes water from the Dobczycki reservoir, constructed as a result of partition of the Raba river bed. Water is collected from three different levels at the tower intake, located on the bank of the reservoir. Water from the intake is pumped to the treatment plant where it enters the ozone contact chamber and then the mixing chambers where the reagents are dosed. Next, water splits into two technological lines: Raba I and Raba II. In the Raba I line, the water with coagulant flows through mixers I, II and III and then goes to the vortex chambers, where the coagulation process begins. Next, water passes to clarifiers and rapid filters. In the Raba II line, water from the mixing chambers is directed to four accelerator clarifiers, where coagulation and sedimentation take place and then to sand-anthracite filters. Finally, water from both lines is collected in clear water tanks and pumped via disinfection chambers to the three Gorzków reservoirs. Water is disinfected with UV lamps and sodium hypochlorite produced with electrolytic method [3].

During water treatment, sludge is produced, which contains both pollutants removed from water and chemicals added to water during treatment (coagulant, carbon, lime). The sludge is discharged from the production line at the following locations: a contact tank (common for both lines), accelerators (RII line), clarifiers (RI line) and filters (lines RI and RII, separately). Sludge from the RII line is transported to six sludge thickeners. On the other hand, in the RI line sludge settles in gravity settlers (4 units), from which is discharged to sludge drying beds (two sets). Sludge drying beds of the RI line comprise two units of area $160 \mathrm{~m}^{2}$ each, the sludge level is $0.65 \mathrm{~m}$ and sludge drying beds of the RII line comprise 14 covered beds ( 8 units of area of $290 \mathrm{~m}^{2}$ and 6 units of area of $490 \mathrm{~m}^{2}$ ); the maximum sludge level $0.85 \mathrm{~m} \mathrm{[3]}$.

\subsection{ZUW Dłubnia}

The Dłubnia water treatment plant supplies water for the metallurgical plant and residents of Nowa Huta. The raw water from the Dłubnia river is coagulated in a coagulation system comprising: coagulant dosing units, rapid mixers, slow mixers and clarifiers. Water from the clarifiers passes through the overflow channel to ten rapid filters. After filtration and disinfection with chlorine dioxide water goes to the "lower" tanks [3].

The sludge from sedimentation processes as well as filter backwash waters flow to a sludge thickener. The supernatant, after settling, is discharged into the sewage system while remaining sludge is pumped to the thickened sludge tank. The sludge moisture is $99 \%$. Further processing involves flocculant dosing and sludge dewatering at a belt press. After serious dewatering sludge moisture is lowered to $35 \%$ [3].

\subsection{ZUW Rudawa}

Water treatment at the ZUW Rudawa involves coagulation with aluminum sulphate and filtration on rapid filters. Raw water is stored in the dam located in the village of Szczyglice and from there it flows into two sedimentation ponds and then to retention reservoirs. Next, water passes to the collection wells located at the plant site and then is pumped successively to four high-speed mixing chambers and slow-speed mixing chambers. After sedimentation 
in clarifiers water is transported to 12 rapid sand filters (filter bed thickness of $1.1 \mathrm{~m}$ ) and then to 6 carbon filters. The filter effluent is disinfected with chlorine dioxide (IV) produced on site [3].

Sludge generated in the course of the treatment process is transported to sludge thickeners and then to a filter press for further dewatering [3].

\subsection{ZUW Bielany}

The oldest water treatment plant in Cracow has been put into operation in 1901. Currently, its production (12-18 thousand $\mathrm{m}^{3} /$ day) is based solely on water from the Sanka river. The water, once stored in the dam, flows through bar screens and the grit chamber to the collecting well. In the well, there are pumps that pump water to the clarifier or on slow filters. In slow filters, raw water passes through a natural filter bed. There are 96 wells near the filtration basins to collect water from the aquifer. The water is drained with siphons to the two collecting wells and then disinfected with sodium hypochlorite generated with a electrolytic method. Finally, water free of microorganisms is discharged to three drinking water tanks [3].

\section{Disscusion of results}

The paper presents analyzes of sludge produced at the ZUWs Raba, Dłubnia and Rudawa, as a technological process by-product. The results include the visual sludge characteristic, i.e. color and consistency as well as other measurable parameters, i.e. $\mathrm{pH}$, dry solids (DS), dry volatile solids (DVS) and capillary suction time (CST).

At the ZUW Raba, both color and consistency of sludge varied with seasons. The sludge produced in summer had the highest density (a solid consistency) and therefore a sample of $10 \mathrm{~g}$ of sludge was needed for DS and DVS analysis; in other tests $50 \mathrm{ml}$ of liquid sludge was required. The sludge $\mathrm{pH}$ turned out to be the most stable parameter and it stayed at approx. 6.7. The highest $\mathrm{pH}$ value as well as the highest CST $(268.10 \mathrm{~s})$ was found in the sample collected in July. The lowest CST was detected in the last measurement series, i.e. in December. The CST value can be directly linked to the sludge consistency. The sludge with a higher moisture and a lower CST releases water more easily.

The lowest content of organic compounds was found in sludge from the ZUW Dłubnia. The maximum value was recorded in summer while the minimum one in fall. The sludge had also high $\mathrm{pH}$, if compared to the sludge produced during treatment of water from the Dobczycki reservoir. The average $\mathrm{pH}$ value was 7.48. The CST was much lower than at the ZUW Raba; the maximum value was recorded in August, while the minimum one in winter.

The mass loss after heating the sample to $550^{\circ} \mathrm{C}$ determines a relative content of organic matter in a water sludge. Higher mass losses (a higher content of organic compounds) are observed during treatment of strongly polluted water as well as water where powdered activated carbon (PAC) was used during coagulation. The PAC content in the sludge increases the amount of organic material, while on the other hand, PAC stabilizes the sludge biologically, reducing its ability to decay [4].

Sludge from surface water coagulation usually has black and gray color due to the presence of humus, clay particles, and in some cases also powdered organic carbon. This color predominated in the sludge from the ZUW Dłubnia and the ZUW Rudawa, both in fall and in winter. 
Table 1. Sludge from the Cracow water treatment plants.

\begin{tabular}{|c|c|c|c|c|c|c|}
\hline Season & Colour & $\begin{array}{c}\text { Consistency } \\
\text { Liquid/semi-liquid } \\
\text { /solid }\end{array}$ & $\mathbf{p H}$ & $\begin{array}{l}\text { Dry solids, } \\
\text { g/dm }\end{array}$ & $\begin{array}{c}\text { Dry volatile } \\
\text { solids, } \mathrm{g} / \mathbf{d m}^{3}\end{array}$ & CST, s \\
\hline \multicolumn{7}{|c|}{ ZUW Raba } \\
\hline Summer & $\begin{array}{l}\text { gray- } \\
\text { brown }\end{array}$ & solid & 6.9 & $117.6 \mathrm{~g} / \mathrm{kg}$ & $32.91 \mathrm{~g} / \mathrm{kg}$ & 268.10 \\
\hline Fall & $\begin{array}{c}\text { black } \\
\text { and gray }\end{array}$ & semi-liquid & 6.79 & 9.52 & 6.58 & 106.98 \\
\hline Winter & $\begin{array}{c}\text { gray and } \\
\text { green }\end{array}$ & liquid & 6.52 & 17.37 & 4.42 & 68.66 \\
\hline \multicolumn{7}{|c|}{ ZUW Dłubnia } \\
\hline Summer & $\begin{array}{c}\text { grey and } \\
\text { brown }\end{array}$ & liquid & 7.23 & 45.91 & 6.31 & 55.79 \\
\hline Fall & $\begin{array}{c}\text { black } \\
\text { and gray }\end{array}$ & liquid & 7.62 & 9.51 & 1.65 & 39.73 \\
\hline Winter & $\begin{array}{c}\text { black } \\
\text { and gray }\end{array}$ & liquid & 7.59 & 10.82 & 3.02 & 31.12 \\
\hline \multicolumn{7}{|c|}{ ZUW Rudawa } \\
\hline Summer & $\begin{array}{c}\text { grey and } \\
\text { brown }\end{array}$ & liquid & 7.26 & 60.53 & 13.88 & 54.06 \\
\hline Winter & $\begin{array}{c}\text { black } \\
\text { and gray }\end{array}$ & liquid & 7.56 & 39.96 & 7.936 & 25.14 \\
\hline Fall & $\begin{array}{c}\text { black } \\
\text { and gray }\end{array}$ & semi-liquid & 6.96 & 56.54 & 10.75 & 92.05 \\
\hline
\end{tabular}

Table 2. DS, DVS and organic content (\%) in sludge at three Cracow water treatment plants.

\begin{tabular}{|c|c|c|c|c|}
\hline & Season & Dry solids, $\mathbf{g} / \mathbf{d m}^{\mathbf{3}}$ & ${\text { Dry volatile solids, } \mathbf{g} / \mathbf{d m}^{\mathbf{3}}}$ & Organic content, \% \\
\hline ZUW Raba & Summer & $117.64 \mathrm{~g} / \mathrm{kg}$ & $32.91 \mathrm{~g} / \mathrm{kg}$ & 28.0 \\
\hline & Fall & 9.52 & 6.58 & 69.1 \\
\hline & Winter & 17.37 & 4.42 & 25.5 \\
\hline ZUW Dłubnia & Summer & 45.91 & 6.31 & 13.7 \\
\hline & Fall & 9.51 & 1.65 & 16.4 \\
\hline & Winter & 10.82 & 3.02 & 27.9 \\
\hline ZUW Rudawa & Summer & 60.53 & 13.88 & 22.9 \\
\hline & Fall & 39.96 & 7.94 & 19.1 \\
\hline & Winter & 56.54 & 10.75 & 19.0 \\
\hline
\end{tabular}

Table 2 summarizes the results of DS, DVS and organic content (\%) in sludge for three water treatment plants at the Cracow agglomeration. The highest organic content was recorded in sludge samples collected at the ZUW Raba. The maximum value over $69 \%$ was observed in fall and it was much higher than the other ones. This may be caused by some accumulation of organic compounds in summer, which resulted in a significantly higher content of an organic material in sludge in November.

The Dobczycki reservoir is located in heavily urbanized areas that may pose a threat to water quality. Also, the basin of the Raba river, the main source of water for the reservoir, still requires some efforts in terms of sewage management control. The inflow of polluted water is one of the reasons for the unsatisfactory water quality in the reservoir. The sources of pollution include: nutrients from municipal sewage, mineral fertilizers or surface runoff from the catchment. A significant input of nutrients to surface waters results in escalation of 
eutrophication processes. Pawełek and Spytek [5] in their research in the years 2003-2005 found that the maximum daily loads of the analyzed nutrients $\left(\mathrm{NO}_{3}, \mathrm{NO}_{2}, \mathrm{NH}_{4}\right.$, $\mathrm{PO}_{4}$ andP $\mathrm{P}_{\text {total }}$ ) were recorded in 2005 . The main nutrient that stimulates eutrophication is phosphorus. The authors pointed out that in 2005 the phosphorus load exceeded more than twenty times the hazardous load and over forty times the acceptable load. The eutrophication process is manifested at first by the ecosystem imbalance and following accumulation of excess organic matter in surface waters [6]. A continuous input of nutrients to the Dobczyce reservoir may therefore have negative effects on quality of water supplied to the Cracow water supply system; nutrients may also be responsible for a higher organic content in the sludge.

Also, the other two plants: ZUW Dłubnia and ZUW Rudawa showed the highest sludge concentrations (DS) in summer (Tab.1); the sludge concentration at the ZUW Rudawa was the highest and reached $60.53 \mathrm{~g} / \mathrm{kg}$. Such high values were also accompanied by the highest concentrations of DVS. The lowest DS and DVS values for both plants were found in fall and can be attributed to weather conditions, i.e. heavy rainfall. In addition, the lower sludge concentrations may result from the particular technology used. At the ZUW Dłubnia, the sludge concentration is kept at a certain level so it can be easily pumped to a belt press for dewatering. At the other two plants, the sludge moisture largely depends on the atmospheric conditions. At the ZUW Rudawa, the sludge is deposited in uncovered thickeners, while at the ZUW Raba on roofed sludge beds, which significantly reduce the weather impact, though do not eliminate it.

Another important parameter defining the water sludge characteristic and possibility of its safe management is a heavy metals content. In Poland, there are no regulations regarding acceptable levels of toxic materials, i.e. heavy metals and other substances. However, according to the American standards, waste is classified as hazardous or toxic based on leaching tests. The tests are carried out according to two procedures EP and TCLP. Monitoring of dangerous substances required for agricultural sludge management depends on the decisions of state bodies. However, the Federal Rules for the Control of Pollutants and Waste Management Rules specify the maximum allowable concentrations of heavy metals in $\mathrm{mg} / \mathrm{kg}$ of sludge, which determine its classification. In Table 1 the maximum allowable concentration of heavy metals in sludge suitable for agricultural use were listed, according to the American standards. The seven heavy metals were specified, which are usually analyzed by the Central Laboratory of Cracow Water Works. Comparing the values with data provided by the Central Laboratory for the sludge from the ZUW Raba, it can be noticed that none of the values exceeds the maximum concentration. Moreover, for six heavy metals the concentrations are much lower than the maximum allowable concentrations [7].

Table 3. Maximum allowable concentrations of heavy metals in sludge used for agriculture, as specified by the Federal Water Pollution Control Act and the Solid Waste Management Act [7].

\begin{tabular}{|c|c|}
\hline Metal & $\begin{array}{c}\text { Maximum allowable concentrations, } \\
\mathbf{m g} / \mathbf{k g} \text { dry solids }\end{array}$ \\
\hline Zinc & 7500 \\
\hline Lead & 840 \\
\hline Copper & 4300 \\
\hline Chromium & 1200 \\
\hline Cadmium & 85 \\
\hline Mercury & 57 \\
\hline Nickel & 420 \\
\hline
\end{tabular}


The capillary suction time tests were carried out to evaluate how easily sludge releases water. The method measures the time of crossing of the frontal boundary layer of filtrate between the concentric circles 32 and $45 \mathrm{~mm}$ in diameter, on the filter paper. The lower capillary sucking time (CST) the more easily (sooner) sludge releases the liquid [8].

Table 4. CST for three water treatment plants and different sludge consistencies.

\begin{tabular}{|c|c|c|c|}
\hline \multirow{2}{*}{ ZUW Raba } & Season & $\begin{array}{c}\text { Consistency solid/semi } \\
\text { liquid/liquid }\end{array}$ & CST, s \\
\cline { 2 - 4 } & summer & solid & 268,10 \\
\cline { 2 - 4 } & fall & semi liquid & 106,98 \\
\hline \multirow{3}{*}{ ZUW Rudawa } & summer & liquid & 68,66 \\
\cline { 2 - 4 } & fall & liquid & 54,06 \\
\cline { 2 - 4 } & winter & liquid & 25,14 \\
\hline \multirow{3}{*}{ ZUW Demi liquid } & 92,05 \\
\cline { 2 - 4 } & summer & liquid & 35,79 \\
\cline { 2 - 4 } & fall & liquid & 39,73 \\
\cline { 2 - 4 } & winter & liquid & 31,12 \\
\hline
\end{tabular}

Table 4 illustrates sludge consistency and sludge CST, as observed in the samples collected at all three water treatment plants. For the ZUW Raba, it was clear that CST varied with a sludge consistency. In summer, when the collected sludge had a solid consistency, the highest CST was recorded; it means that the samples did not release water easily. In the next sample (November 10) the CST was more than a half of the summer sample. The consistency of the sludge also changed; it was semi-liquid in fall. The lowest CST equal to $68.66 \mathrm{~s}$ was recorded for the last liquid sample, taken in December. The sludge collected in winter dewatered easily. The highest CST was recorded in the semi-liquid sludge samples at the ZUW Rudawa, in winter. The results obtained for the ZUW Dłubnia and the ZUW Raba were similar; they showed the lower CST values for the lower air temperatures. In summer, CST was $55.79 \mathrm{~s}$ and it was close to CST measured in summer for sludge from sludge drying beds at the ZUW Rudawa.

\section{Summary}

According to current regulations, water sludge poses a significant environmental problem. The ways of its utilization are mostly determined by its properties and physic-chemical characteristic, while the strong trend of the closed-circuit economy forces the scientists to look for new ways of sludge handling. Water sludge may be utilized as a substrate in some technological processes but its by-products should be significantly reduced. In addition, heavy metals in sludge limits a possibility of its use in agriculture, which until now was a popular practice. Therefore, it is necessary to look for new options for sludge management, that are possible to use in a technological scale and consider all restrictions resulting from the legal provisions.

\section{References}

1. A. Nawrocka, M. Włodarczyk-Makuła, Tech. Wod. 34-39 (2014)

2. A. L. Kowal, M. Świderska-Bróż, Oczyszczanie wody. Podstawy teoretyczne i technologiczne procesy i urządzenia (2009) 
3. MPWiK S.A. Informacje udostępnione przez Miejskie Przedsiębiorstwo Wodociągów i Kanalizacji Spółka Akcyjna w Krakowie (2016)

4. A. Florkiewicz, Technologia usuwania i unieszkodliwiania osadów z uzdatniania wody (1999).

5. J. Pawełek, M Spytek, Infrastruktura i Ekologia Terenów Wiejskich 3, 1, 107-116 (2006)

6. E. Neverova-Dziopak, Z. Kowalewski, Czas. Inż. Ląd., Środ. i Arch. 7-9, 47-58 (2013)

7. M. Leszczyńska, M. M. Sozański, Ochr. Środ. i Zas. Nat (2009)

8. A. Piotrowska-Cyplik, Z. Czarnecki, Journ. of Res. and Appl. in Agr. Eng. 50, 1 (2005)

9. I. Płonka, Met. cięż. wos. pow. przy uzd. wod. (2012) 